\title{
Adaptation of anthurium cultivars as cut flowers in a subtropical area
}

\author{
Adriane Marinho de Assis(1), Lilian Keiko Unemoto(1), Ricardo Tadeu de Faria(1), Deonísio Destro(1), \\ Lúcia Sadayo Assari Takahashi(1), Sérgio Ruffo Roberto(1), Sandra Helena Prudêncio(1) \\ and Antonio Fernando Caetano Tombolato(2)
}

\begin{abstract}
(1)Universidade Estadual de Londrina, Departamento de Agronomia, Caixa Postal 6001, CEP 86051-990 Londrina, Paraná, Brazil. E-mail: agroadri@ig.com.br, lilianunemoto@yahoo.com.br, faria@uel.br, deonisiodestro@yahoo.com, sadayo@uel.br, sroberto@uel.br, sandrah@uel.br (2)Instituto Agronômico de Campinas, Avenida Theodureto de Almeida Camargo, no 1.500, Vila Nova, Caixa Postal 28, CEP 13075-630 Campinas, São Paulo, Brazil. E-mail: tombolat@iac.sp.gov.br
\end{abstract}

\begin{abstract}
The objective of this work was to evaluate the adaptation of anthurium (Anthurium andraeanum) cultivars as cut flowers in a subtropical area, located in north of Paraná State, Brazil. The Apalai, Ianomami, Kinã, nK 102, Parakanã, Rubi, and Terena cultivars were cultivated in a nursery under $80 \%$ shade. The number of leaves and inflorescences, floral stem length, length and width of inflorescences, and spadix length were evaluated. The experimental design was in completely randomized blocks, with six replicates and five plants per plot. During the 18 months evaluated, 'Parakanã' produced 11 inflorescences per plant, whereas the other cultivars produced seven to nine inflorescences per plant. The number of leaves produced per plant was: 'Ianomami', 25; 'Parakanã', 20; 'Apalai' and 'Terena', 15; 'Kinã' and 'Rubi', 11; and 'nK 102', 9. The Apalai, nK 102, Parakanã, and Rubi cultivars are the most recommended as cut flowers; the Ianomami cultivar is not recommended as a cut flower in this region.
\end{abstract}

Index terms: Anthurium andraeanum, ornamental plants, tropical flowers.

\section{Adaptação de cultivares de antúrio como flor de corte em área subtropical}

\begin{abstract}
Resumo - O objetivo deste trabalho foi avaliar a adaptação de cultivares de antúrio como flor de corte em área subtropical, localizada no norte do estado do Paraná. As cultivares Apalai, Ianomami, Kinã, nK 102, Parakanã, Rubi e Terena foram cultivadas em viveiro com $80 \%$ de sombreamento. Foram avaliados o número de folhas e inflorescências, comprimento da haste floral, comprimento e largura das inflorescências e comprimento da espádice. O delineamento experimental foi inteiramente casualizado, com seis repetições e cinco plantas por parcela. Durante os 18 meses de cultivo, a cultivar Parakanã produziu 11 inflorescências por planta, enquanto as demais produziram de sete a nove inflorescências por planta. $\mathrm{O}$ número de folhas produzidas por planta foi: 'Ianomami', 25; 'Parakanã', 20; 'Apalai' e 'Terena', 15; 'Kinã' e 'Rubi', 11; e 'nK 102', nove. As cultivares Apalai, nK 102, Parakanã e Rubi são as mais indicadas como flores de corte; a cultivar Ianomami não é recomendada como flor de corte nessa região.
\end{abstract}

Termos para indexação: Anthurium andraeanum, planta ornamental, flores tropicais.

\section{Introduction}

Tropical floriculture is under expansion, and is classified as a business with good incomes, thus a considerable alternative for small rural areas (Terao et al., 2005; Junqueira \& Peetz, 2010).

Anthurium (Anthurium sp.) is an important tropical cut flower, which belongs to the family Araceae and is originated from South and Central America (Coelho \& Catharino, 2005). The main species of the genus, Anthurium andraeanum Linden, from Venezuela and Colombia, is preferred over the others because of its size, flower colors and post-harvest durability (Joly, 1977; Tombolato et al., 2004; Terao et al., 2005).
Anthurium is cultivated in several countries, such as the Netherlands, which is the main producer and exporter of this cut flower. In Brazil, São Paulo state is considered one of the largest production and commercialization centers, concentrated in the regions of Holambra, Atibaia, and Vale do Ribeira. However, the states of Bahia, Ceará and Pernambuco are potential production centers (Leme \& Honório, 2004b; Caldari Júnior, 2004).

As a tropical plant from warm, shaded and humid forests, anthurium requires management techniques which ensure similar conditions for its proper cultivation, i.e., daytime temperatures between 20 and $28^{\circ} \mathrm{C}$, and night temperatures above $18^{\circ} \mathrm{C}$; humidity 
above $50 \%$ in sunny days, between 70 and $80 \%$ in cloudy days, and up to $90 \%$ at night. Light intensity should be controlled, since light acts directly on photosynthesis; according to Tombolato (2004), the cultivation of anthurium should be done in an area protected from sunlight, with 50 to $90 \%$ shading.

Each species has its own developmental requirements (Reid et al., 1991). Therefore, certain factors should be taken into account for the success of anthurium production, such as: cultivar selection, use of proper inputs, weed and disease controls, as well as production, harvest, and post-harvest technology (Leme \& Honório, 2004a). Furthermore, it is important to use good propagating material, since anthurium can be propagated by seeds or asexually (Tombolato, 2004).

For anthurium cultivar selection, special attention must be given to the following requirements: brightness of the spadix; spathe firmness with evident venation; equal, well-developed, superposed or merged spathe basal lobes; contrasting colors, with white or yellow sections; and spadix with two thirds or three quarters of the length of the spathe (Tombolato et al., 2002). The flower stem must be erect, firm, with a minimal length of $60 \mathrm{~cm}$, and a set of five or more flowers per plant per year. Longevity must surpass twenty days after harvest, and the plants must have short internodes with compact growth, and show resistance or tolerance to diseases.

Paraná state, in Southern Brazil, has a climate that varies from subtropical, in the north, to temperate, in the south, which makes it possible to cultivate species with a wide array of environmental requirements. However, $96 \%$ of the flower market is supplied with flowers produced in São Paulo state. According to Tombolato et al. (2004), Anthurium hybridization has produced plants and flowers of several shapes and color patterns, which evidences its potential cultivation in Paraná.

One of the main objectives of the breeding programs is the identification of genotypes with high yield, production stability, and wide adaptability to many environments (Destro \& Montalván, 1999). The study of adaptability and phenotypic stability of genotypes is very important, since it furnishes information regarding the response of each genotype to different environmental conditions (Cruz et al., 2004), and is an essential tool to ensure success in the recommendation of cultivars (Cruz \& Castoldi, 1991; Sudaric et al., 2006).
The objective of this work was to evaluate the adaptation of anthurium cultivars as cut flowers in a subtropical area, located in north of Paraná State, Brazil.

\section{Materials and Methods}

The experiment was carried out from May 2006 to November 2007 at the Universidade Estadual de Londrina, Paraná, Brazil $\left(23^{\circ} 23^{\prime} \mathrm{S}\right.$ and $51^{\circ} 11^{\prime} \mathrm{W}$, at 566-m altitude). The climate is classified as $\mathrm{Cfa}$, humid subtropical, according to Köppen.

The following $A$. andraeanum cultivars, developed by the Instituto Agronômico de Campinas, São Paulo, Brazil, were evaluated: Apalai, Kinã, Ianomami, nK 102, Parakanã, Rubi, and Terena.

In vitro propagated seedlings of all cultivars, supplied by ClonAgri (ClonAgri, São Paulo, SP, Brazil), were acclimatized in an arched-roof greenhouse with $80 \%$ shade given by black polypropylene screens, and, then, transplanted into beds in the nursery $(10 \mathrm{~m}$ long, $10 \mathrm{~m}$ wide, and $2 \mathrm{~m}$ high) covered with a polypropylene screen to retain $80 \%$ of solar radiation. The seedlings were planted with a $0.4 \times 0.4 \mathrm{~m}$ spacing, and the number of leaves per plant was standardized at five.

The soil analysis of the beds, in April 2006, showed clayey soil with $\mathrm{pH}$ of 6.0 , which is the standard for anthurium cultivation, according to Barbosa (1999).

Irrigation by aspersion was carried out early in the morning, three to four times per week, in summer, and one to two times per week in winter. The data regarding temperature and relative humidity in the nursery were recorded daily (Figure 1).

Plants were fertilized according to Tombolato (2002) with 200, 100 and $150 \mathrm{~kg} \mathrm{ha}^{-1}$ per year of nitrogen, phosphorus and potassium, respectively, in four applications. The first fertilization was carried out at transplantation, and repeated every three months.

Every 30 days, weeds were manually removed and leaves were pruned. A malathion-based insecticide was used for pest control. The assessments began 120 days after transplantation with monthly inflorescences counting and bimonthly evaluation of the floral stem length, length of the spadix and spathe. The leaves were counted six months after the beginning of the experiment. A randomized design was used with six replicates and five plants per plot. The data were submitted to analysis of variance, and the means compared through the Tukey test, at 5\% probability. 


\section{Results and Discussion}

All cultivars showed distinct traits for all characters evaluated. The first cultivar to produce spathes was Rubi, in August 2006 (three months after transplantation); the others produced spathes in
September 2006, except for Ianomami, which did not flower during the experiment (Figure 2). Takahashi et al. (2009), in a three-year period experiment with potted plants of the same cultivars, in the same region, found that 'Ianomami' did not produce inflorescences during this period.

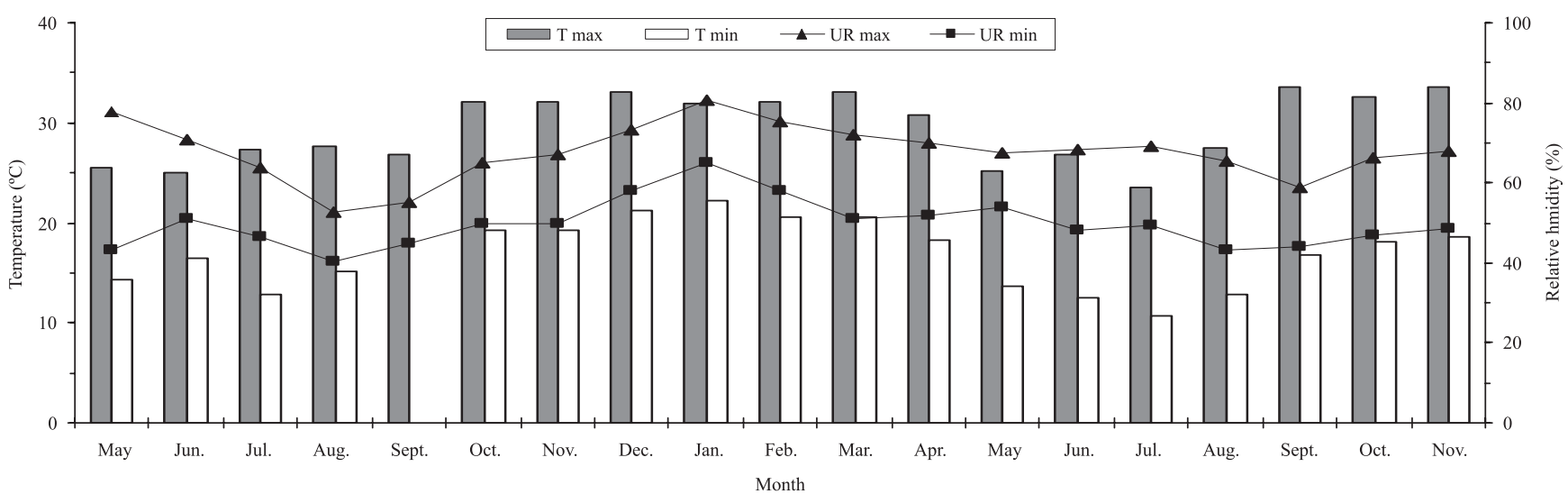

Figure 1. Monthly averages of Temperature $\left({ }^{\circ} \mathrm{C}\right)$ and Relative humidity $(\%)$ in Londrina, north of Paraná State, Brazil, from May 2006 to November 2007.
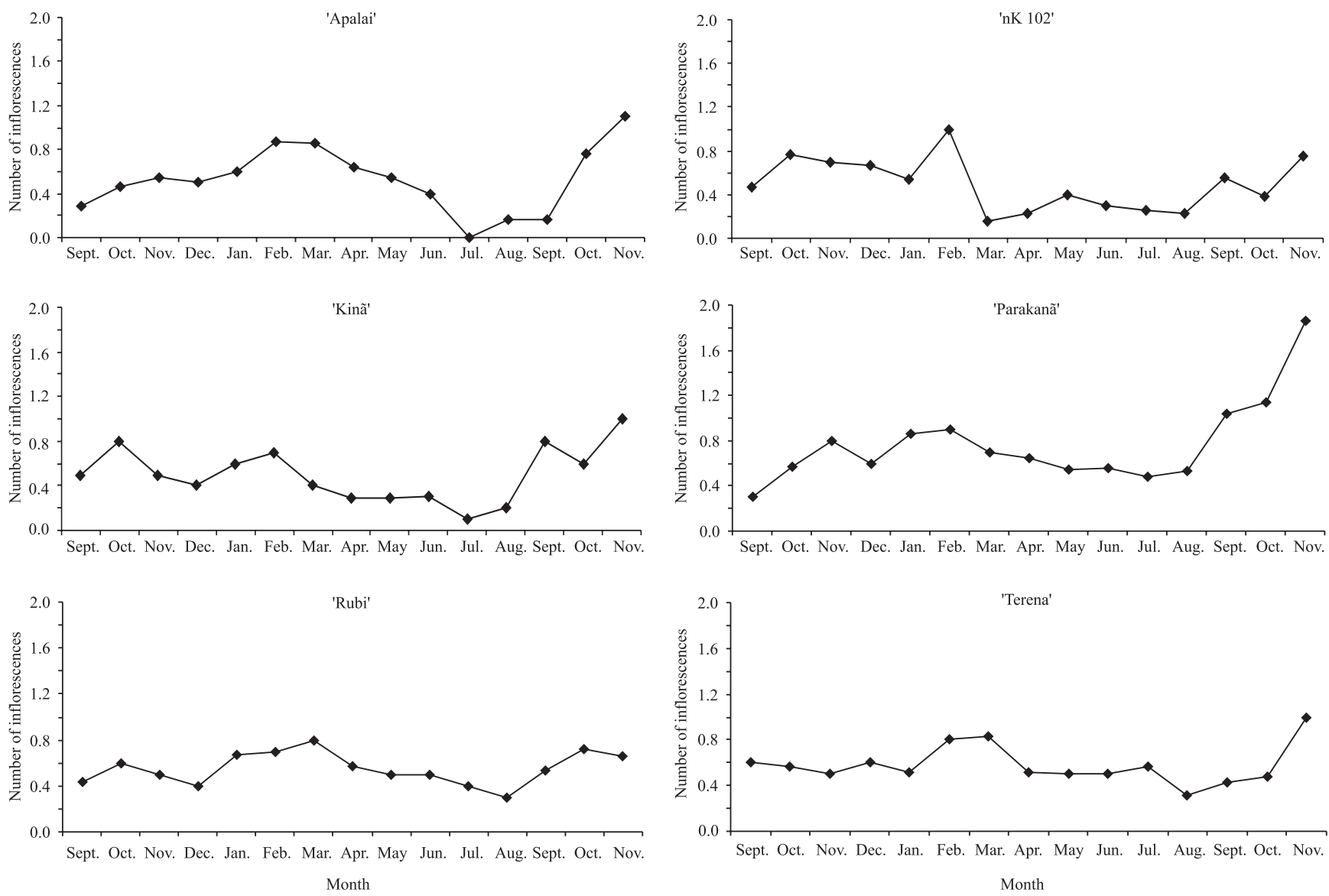

Figure 2. Inflorescences produced by the Apalai, Kinã, nK 102, Parakanã, Rubi, and Terena cultivars of Anthurium andraeanum in north of Paraná State, Brazil, from September 2006 to November 2007. 
Parakanã was the most productive cultivar, producing approximately 11 inflorescences during the 18-month cultivation period, with a mean of 7.3 inflorescences per year; the other cultivars produced between seven and nine inflorescences, with a mean of 4.6 to 6 inflorescences per year. In plants cultivated in Ceará state, Brazil, Paiva et al. (2004) observed yearly spathe yields for other cultivars that were significantly lower in comparison to those found in this research (between 1.6 and 2.9), while Tombolato et al. (2006), in Vale do Ribeira, São Paulo State, Brazil, reported similar yields.

The peak of inflorescence production (Figure 2) was observed in October 2006 and November 2007 for 'Kinã'; in March and November 2007, for 'Apalai' and 'Terena'; in March 2007 for 'nK 102'; in March and October 2007 for 'Rubi'; and from September to November 2007, months in which the mean maximum temperature was above $32^{\circ} \mathrm{C}$ (Figure 1), for 'Parakanã'. A reduction in the number of 'Apalai' inflorescences was observed from May to July 2007. This could be related to temperature decrease, especially in July (Figure 1), as well as to low light intensity and shorter days.
Grossi \& Cuquel (2004) reported that, in some municipalities of Paraná, Brazil, anthurium cropping is difficult due to low temperatures and frequent frosts during the winter.

According to Tombolato et al. (2002), anthurium must be grown in regions with night minimum temperatures above $18^{\circ} \mathrm{C}$ and day maximum temperatures equal or below $35^{\circ} \mathrm{C}$; the ideal range is between 20 and $28^{\circ} \mathrm{C}$. However, from May to September 2006 and 2007, although the minimum temperature was below the recommended, all cultivars (except Ianomami) produced flowers, evidencing their adaptability.

The mean values regarding the relative humidity of the air (Figure 1) remained within the recommended range for the culture, which in sunny days must be over $50 \%$ and in cloudy days between 70 and $80 \%$ (Barbosa, 1999; Tombolato, 2004).

The values for floral stem length are found in Table 1. The cultivar $\mathrm{nK} 102$ had the highest means, followed by Kinã, Rubi, Parakanã, Apalai and Terena. No statistically significant difference was found for the cultivars in September 2006 and 2007, and July 2007.

The length of the floral stem is a very important character for the classification, standardization, and

Table 1. Floral stem, spadix and spathe lengths of Anthurium andraeanum cultivars, in north of Paraná State, Brazil, from September 2006 to November $2007^{(1)}$.

\begin{tabular}{|c|c|c|c|c|c|c|c|c|}
\hline Cultivar & September & November & January & March & May & July & September & November \\
\hline & \multicolumn{8}{|c|}{ Floral stem length (Cm) } \\
\hline Apalai & $23.9 \mathrm{a}$ & $30.5 b$ & $41.1 \mathrm{ab}$ & $41.7 \mathrm{c}$ & $47.5 \mathrm{~cd}$ & -(2) & $37.1 \mathrm{a}$ & $41.5 \mathrm{~cd}$ \\
\hline Kinã & $35.3 \mathrm{a}$ & $38.4 \mathrm{~b}$ & $38.1 \mathrm{~b}$ & $52.0 \mathrm{~b}$ & $64.4 \mathrm{ab}$ & $55.4 \mathrm{a}$ & $44.1 \mathrm{a}$ & $50.7 \mathrm{ab}$ \\
\hline nK 102 & $38.4 \mathrm{a}$ & $51.2 \mathrm{a}$ & $54.8 \mathrm{a}$ & $65.3 \mathrm{a}$ & $72.2 \mathrm{a}$ & $46.6 \mathrm{a}$ & $46.1 \mathrm{a}$ & $61.4 \mathrm{a}$ \\
\hline Parakanã & $34.4 \mathrm{a}$ & $33.6 b$ & $41.3 \mathrm{ab}$ & $45.1 b c$ & $49.1 \mathrm{~cd}$ & $45.5 \mathrm{a}$ & $41.3 \mathrm{a}$ & $46.9 \mathrm{bcd}$ \\
\hline Rubi & $35.2 \mathrm{a}$ & $34.2 b$ & $48.4 \mathrm{ab}$ & $49.1 \mathrm{bc}$ & $56.8 \mathrm{bc}$ & $46.1 \mathrm{a}$ & $48.1 \mathrm{a}$ & $49.7 \mathrm{abc}$ \\
\hline Terena & $27.2 \mathrm{a}$ & $34.7 \mathrm{~b}$ & $38.7 \mathrm{~b}$ & $43.1 \mathrm{bc}$ & $41.8 \mathrm{~d}$ & $37.1 \mathrm{a}$ & $40.1 \mathrm{a}$ & $37.5 \mathrm{~d}$ \\
\hline \multirow[t]{2}{*}{$\mathrm{CV}(\%)$} & 23.1 & 11.7 & 15.5 & 10.2 & 9.5 & 20.3 & 33.8 & 12.9 \\
\hline & \multicolumn{8}{|c|}{ Spadix length $(\mathrm{cm})$} \\
\hline Apalai & $4.9 \mathrm{~d}$ & $4.8 \mathrm{a}$ & $6.4 \mathrm{bc}$ & $6.2 b$ & $7.4 \mathrm{bc}$ & - & $8.9 \mathrm{ab}$ & $6.9 \mathrm{~cd}$ \\
\hline Kinã & $8.0 \mathrm{ab}$ & $8.1 \mathrm{a}$ & $6.2 \mathrm{bc}$ & $8.8 \mathrm{a}$ & $10.1 \mathrm{a}$ & $10.3 \mathrm{a}$ & $10.8 \mathrm{a}$ & $10.1 \mathrm{a}$ \\
\hline nK 102 & 7.3abc & $7.8 \mathrm{a}$ & $8.4 \mathrm{a}$ & $9.1 \mathrm{a}$ & $8.7 \mathrm{ab}$ & $9.6 \mathrm{a}$ & $10.3 \mathrm{a}$ & $9.1 \mathrm{ab}$ \\
\hline Parakanã & $5.5 \mathrm{~cd}$ & $6.6 \mathrm{a}$ & $5.5 \mathrm{c}$ & $5.1 \mathrm{~b}$ & $5.7 \mathrm{c}$ & $6.3 b$ & $6.7 \mathrm{~b}$ & $5.9 \mathrm{~d}$ \\
\hline Rubi & $5.8 \mathrm{bcd}$ & $5.8 \mathrm{a}$ & $6.7 \mathrm{abc}$ & $6.2 b$ & $7.3 \mathrm{bc}$ & $7.5 b$ & $8.5 \mathrm{ab}$ & $8.2 b c$ \\
\hline Terena & $8.7 \mathrm{a}$ & $7.1 \mathrm{a}$ & $7.7 \mathrm{ab}$ & $8.5 \mathrm{a}$ & $8.9 \mathrm{ab}$ & $8.4 \mathrm{ab}$ & $9.1 \mathrm{ab}$ & $8.4 \mathrm{~b}$ \\
\hline \multirow[t]{2}{*}{ CV $(\%)$} & 15.4 & 29.6 & 11.5 & 10.3 & 8.8 & 8.8 & 14.0 & 8.5 \\
\hline & \multicolumn{8}{|c|}{ Spathe length (cm) } \\
\hline Apalai & $6.1 \mathrm{c}$ & $6.7 \mathrm{c}$ & $7.9 \mathrm{~cd}$ & $7.8 \mathrm{bc}$ & $8.6 \mathrm{~cd}$ & - & $9.7 \mathrm{~cd}$ & $8.9 \mathrm{~d}$ \\
\hline Kinã & $10.8 \mathrm{ab}$ & $11.1 \mathrm{~b}$ & $10.7 \mathrm{bc}$ & $10.5 b$ & $13.2 \mathrm{~b}$ & $15.7 \mathrm{a}$ & $14.1 \mathrm{~b}$ & $14.5 \mathrm{bc}$ \\
\hline nK 102 & $13.4 \mathrm{a}$ & $15.8 \mathrm{a}$ & $16.0 \mathrm{a}$ & $15.9 \mathrm{a}$ & $17.8 \mathrm{a}$ & $16.2 \mathrm{a}$ & $18.6 \mathrm{a}$ & $19.3 \mathrm{a}$ \\
\hline Parakanã & $6.4 \mathrm{c}$ & $5.9 \mathrm{c}$ & $6.7 \mathrm{~d}$ & $6.2 \mathrm{c}$ & $7.2 \mathrm{~d}$ & $7.6 \mathrm{c}$ & $8.5 \mathrm{~d}$ & $7.9 \mathrm{~d}$ \\
\hline Rubi & $8.1 \mathrm{bc}$ & $8.7 b c$ & $0.5 b c$ & $9.6 b$ & $11.2 b c$ & $10.7 b c$ & $12.2 \mathrm{bc}$ & $12.2 \mathrm{c}$ \\
\hline Terena & $11.6 \mathrm{a}$ & $11.1 \mathrm{~b}$ & $2.5 \mathrm{~b}$ & $14.4 \mathrm{a}$ & $14.6 \mathrm{ab}$ & $14.1 \mathrm{ab}$ & $13.7 \mathrm{~b}$ & $15.1 \mathrm{~b}$ \\
\hline CV (\%) & 16.1 & 16.8 & 3.5 & 2.5 & 12.9 & 11.0 & 15.1 & 11.5 \\
\hline
\end{tabular}

${ }^{(1)}$ Means followed by equal letters, in the columns, do not differ by the Tukey test, at $5 \%$ probability. ${ }^{(2)}$ The Apalai cultivar did not flower in July. 
commercialization of cut flowers, since it interferes in the preparation of floral arrangements. Anthurium stems can be classified as short (less than $30 \mathrm{~cm}$ ), medium (between 30 and $45 \mathrm{~cm}$ ) or long (over $45 \mathrm{~cm}$ ) (Loges et al., 2005).

No statistically significant difference was found for the length of the spadix in November 2006. In the other months the cultivars Kinã, nK 102 and Terena produced longer spadices (Table 2 ). These results agree with those obtained by Takahashi et al. (2009), who, while assessing the Apalai, Parakanã, Rubi, and Terena cultivars, reported that Terena showed the longest spadices. In Ceará state, Brazil, with the Astral, Netuno, Iguape, Cananéia, and Islã cultivars, Paiva et al. (2004) found that Iguape produced the longest spadices. These cultivars have shorter spadices in comparison to those of the present study, except for the values obtained in September and November 2006 for Apalai, and March 2007 for Parakanã.

Statistically significant differences were found for spathe length (Table 3 ) in all assessments; the cultivars Kinã, nK 102 and Terena had the highest means, due to the length and width of the spadix. Takahashi et al. (2009) observed the largest spathes and spadices in 'Terena', followed by 'Rubi', 'Apalai', and 'Parakanã'. According to these authors, among the tested cultivars, Terena showed the best characteristics for pot cultivation due to its longer spathes and shorter floral stems.

There was an increase in the number of leaves (Figure 3) after a year of cultivation. In the eighteenth

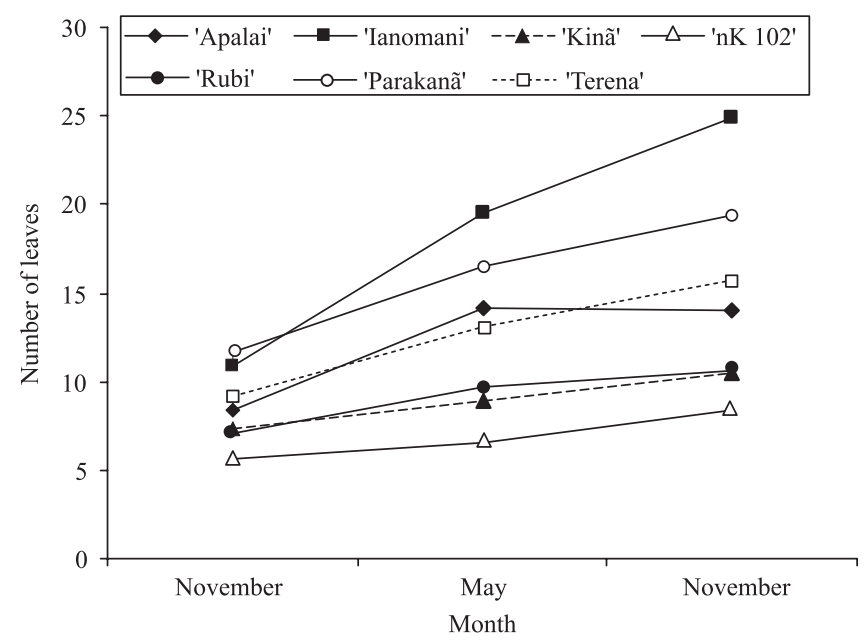

Figure 3. Number of leaves produced by the Apalai, Ianomami, Kinã, nK 102, Parakanã, Rubi and Terena cultivars of Anthurium andraeanum in north of Paraná State, Brazil, in November 2006, and May and November 2007. month, 'Ianomami' had approximately 25 leaves; 'Parakanã', 20; 'Apalai' and 'Terena', 15; 'Kinã' and 'Rubi', 11; and 'nK 102', nine leaves (Figure 3). Thirty-six months after the plantation in pots, Takahashi et al. (2009) observed that 'Parakanã' had the same number of leaves as in this experiment; all the other cultivars had a significantly higher number of leaves. This could be a consequence of the plant development phase when planted, as well as the longer time of the potted plant experiment. Since the leaves are highly commercialized, from the economic point of view, they add value to the plant.

Except for the cultivar Ianomami, all others adapted to the climatic conditions of north of Paraná. The cultivars nK 102 and Kinã showed long stems and spadices, which are greatly appreciated for floral arrangements; nK 102 was the most accepted by consumers. The Parakanã cultivar was the most productive, with higher profitability; it has short spadices and light coloration, a good option for floral arrangements, especially for weddings and religious celebrations. The Apalai and Rubi cultivars are preferred locally and may be used as red cut flowers. The Terena cultivar, with long spadices, but short stems, may not be appropriate for some types of floral arrangements. Thus, the cultivars Apalai, nK 102, Parakanã, and Rubi are the most recommended for an alternative production and source of income for family-based businesses in a subtropical climate.

\section{Conclusions}

1. Anthurium cultivation is suited to the subtropical climate of north of Paraná State, Brazil.

2. Apalai, nK 102, Parakanã and Rubi cultivars have high potential for commercial cultivation as cut flowers in north of Paraná State, Brazil.

3. The Yanomami cultivar is not indicated for planting in the region.

\section{Acknowledgements}

To Coordenação de Aperfeiçoamento Pessoal de Nível Superior and Conselho Nacional de Desenvolvimento Cientifico e Tecnológico, for scholarships granted.

\section{References}

BARBOSA, J.G. Produção comercial de antúrio, helicônia e spathiphyllum: manual. Viçosa: CPT, 1999. 38p. (CPT. Floricultura, 227). 
CALDARI JUNIOR, P. Técnicas de cultivo de antúrio (Anthurium andraeanum). Revista Brasileira de Horticultura Ornamental, v.10, p.43-45, 2004.

COELHO, M.A.N.; CATHARINO, E.L.M. Duas espécies novas de Anthurium Schott (Araceae) para o Brasil. Rodriguésia: Revista do Jardim Botânico do Rio de Janeiro, v.56, p.35-41, 2005.

CRUZ, C.D.; CASTOLDI, F.L. Decomposição da interação genótipos $\mathrm{x}$ ambiente em partes simples e complexa. Revista Ceres, v.38, p.422-430, 1991.

CRUZ, C.D.; REGAZZI, A.J.; CARNEIRO, P.C.S. Modelos biométricos aplicados ao melhoramento genético. 3.ed. Viçosa: UFV, 2004. 480p.

DESTRO, D.; MONTALVÁN, R. Melhoramento genético de plantas. Londrina: UEL, 1999. 818p.

GROSSI, M.L.; CUQUEL, F.L. Diagnóstico da produção de antúrio no Estado do Paraná. Revista Brasileira de Horticultura Ornamental, v.10, p.35-37, 2004.

JOLY, A.B. Botânica: introdução à taxonomia vegetal. 4.ed. São Paulo: Nacional, 1977. 777p.

JUNQUEIRA, A.H.; PEETZ, M. da S. Análise conjuntural do comércio exterior da floricultura brasileira. Disponível em: $<$ http://www.hortica.com.br/artigos/2010_1_Sem_Com_Exterior_ Floricultura_Brasileira.pdf $>$. Acesso em: 21 fev. 2011.

LEME, J.M.; HONÓRIO, S.L. Embalagem de antúrio. Revista Brasileira de Horticultura Ornamental, v.10, p.51-52, 2004a.

LEME, J.M.; HONÓRIO, S.L. Padronização e qualidade de antúrio. Revista Brasileira de Horticultura Ornamental, v.10, p.48-50, 2004b.

LOGES, V.; TEIXEIRA, M.C.; CASTRO, A.C.R. de; COSTA, A.S. Colheita, pós-colheita e embalagem de flores tropicais em Pernambuco. Horticultura Brasileira, v.23, p.699-702, 2005.
PAIVA, W.O. de; CAVALCANTE, R.A.; MOURA, L. de. Melhoramento genético de antúrio no Ceará. Revista Brasileira de Horticultura Ornamental, v.10, p.10-13, 2004.

REID, D.M.; BEALL, F.D.; PHARIS, R.P. Environmental cues in plant growth and development. In: STEWARD, F.C. (Ed.). Plant physiology: a treatise. San Diego: Academic Press, 1991. v.10, p.65-181.

SUDARIC, A.; SIMIC, D.; VRATARIC, M. Characterization of genotype by environment interactions in soybean breeding programmes of Southeast Europe. Plant Breeding, v.125, p.191-194, 2006.

TAKAHASHI, L.S.A.; FARIA, R.T.; TOMBOLATO, A.F.C.; CUQUEL, F.L.; CROSSI, M.L. Desenvolvimento de cultivares de antúrio IAC como plantas de vaso no norte do Paraná. Bragantia, v.68, p.593-600, 2009.

TERAO, D.; CARVALHO, A.C.P.P.; BARROSO, T.C. da S.F. Flores tropicais. Brasília: Embrapa Informação Tecnológica; Fortaleza: Embrapa Agroindústria Tropical, 2005. 225p.

TOMBOLATO,A.F.C. Cultivo comercial de plantas ornamentais. Campinas: Instituto Agronômico, 2004. 211p.

TOMBOLATO, A.F.C.; RIVAS, E.B.; COUTINHO, L.N.; BERGMANN, E.C.; IMENES, S.L.; FURLANI, P.R.; CASTRO, C.E.F.; MATTHES, L.A.F.; SAES, L.A.; COSTA, A.M.M.; TAGLIACOZZO, G.M.D.; LEME, J.M. O cultivo de antúrio: produção comercial. Campinas: Instituto Agronômico, 2002. 47p. (Instituto Agronômico. Boletim técnico, 194).

TOMBOLATO, A.F.C.; SAES, L.A.; MATTHES, L.A.F.; CASTRO, C.E.F. de; SAKAI, M.; TAGLIACOZZO, G.M.D.; UZZO, R.P.; NOMURA, E. 'IAC Isla': nova cultivar de antúrio (Anthurium andreanum Linden) branca para flor de corte. Revista Brasileira de Horticultura Ornamental, v.12, p.61-63, 2006.

TOMBOLATO, A.F.C.; UZZO, R.P.; CASTRO, A.C.R. de; SAKAI, M.; SAES, L.A. Recursos genéticos e melhoramento do antúrio (Anthurium andreanum Linden) no IAC-APTA. Revista Brasileira de Horticultura Ornamental, v.10, p.1-5, 2004.

$\overline{\text { Received on September 16, } 2010 \text { and accepted on January 23, } 2011}$ 